\title{
ANALISIS FAKTOR-FAKTOR DALAM PERSPEKTIF FRAUD TRIANGLE SEBAGAI PREDIKTOR FRAUDULENT FINANCIAL REPORTING
}

\author{
I Gusti Putu Oka Surya Utama ${ }^{1}$ \\ I Wayan Ramantha ${ }^{2}$ \\ I Dewa Nyoman Badera ${ }^{3}$
}

\author{
${ }^{1}$ Fakultas Ekonomi dan Bisnis Universitas Udayana (Unud), Bali, Indonesia \\ email: gbokasurya@gmail.com \\ ${ }^{2}$ Fakultas Ekonomi dan Bisnis Universitas Udayana (Unud), Bali, Indonesia \\ ${ }^{3}$ Fakultas Ekonomi dan Bisnis Universitas Udayana (Unud), Bali, Indonesia
}

\begin{abstract}
ABSTRAK
Tereduksinya kualitas informasi pelaporan keuangan diakibatkan oleh perilaku manajemen yang melakukan tindakan kecurangan dengan cara memanipulasi pelaporan keuangan agar terlihat baik. Penelitian ini bertujuan untuk mendapatkan bukti empiris pengaruh faktor-faktor fraud triangle yaitu financial stability, external pressure, personal financial need, financial targets, nature of industry, ineffective monitoring, organizational structure, dan auditor switching pada fraudulent financial reporting di perusahaan nonkeuangan yang terdaftar di Bursa Efek Indonesia periode 2012-2014. Sampel ditentukan dengan teknik purposive sampling, maka didapatkan 156 jumlah sampel sebagai amatan. Data diamati dengan metode regresi logistik. Hasil membuktikan bahwa unsur pressure yaitu financial stability, external pressure, dan personal financial need berpengaruh positif pada fraudulent financial reporting. Unsur opportunity yaitu organizational structure berpengaruh negatif pada fraudulent financial reporting. Unsur rationalization yaitu auditor switching berpengaruh positif pada fraudulent financial reporting. Sedangkan financial targets, nature of industry, dan ineffective monitoring tidak berpengaruh.
\end{abstract}

Kata kunci: fraud triangle, fraudulent financial reporting, pelanggaran aturan Bapepam-LK

\begin{abstract}
The reduction of financial reporting information's quality is caused by management fraud behavior by manipulate the financial reporting in order to looks good. This research aims to obtain empirical evidence the effect of fraud triangle factors are financial stability, external pressure, personal financial need, financial targets, nature of industry, ineffective monitoring, organizational structure, and auditor switching to fraudulent financial reporting in nonfinancial companies which listed in Indonesia Stock Exchange period 20122014. The sample determined by utilizing purposive sampling technique, therefore as many as 156 of observation sample was obtained. The data observed by logistic regression analysis method. The results show that pressure element these are financial stability, external pressure, and personal financial need has a positive effect to fraudulent financial reporting. Opportunity element these are organizational structure has a negative effect to fraudulent financial reporting. Rationalization element, auditors switching has a positive effect to fraudulent financial reporting. Meanwhile financial targets, nature of industry, and ineffective monitoring have no effect.

Keywords: $\quad$ fraud triangle, fraudulent financial reporting, Bapepam- $L K$ 's violation
\end{abstract}




\section{PENDAHULUAN}

Laporan keuangan sebagai media bagi perusahaan untuk menyediakan informasi bagi para pemakai harus bebas dari salah saji material yang disebabkan oleh kekeliruan (error) ataupun kecurangan (fraud) agar tidak menyesatkan bagi pengguna laporan keuangan. Standar Profesional Akuntan Publik (SPAP) pada Pernyataan Standar Akuntansi (PSA) No. 70 mendefinisikan kecurangan pelaporan keuangan sebagai salah saji atau penghilangan secara sengaja jumlah atau pengungkapan dalam laporan keuangan untuk mengelabui pemakai laporan keuangan dan efek yang timbul adalah ketidaksesuaian laporan keuangan dalam semua hal yang material dengan prinsip akuntansi berterima umum.

Sepanjang tahun 2011, Badan Pengawas Pasar Modal dan Lembaga Keuangan (Bapepam-LK) yang sejak 31 Desember tahun 2012 kewenangan tersebut sudah diambil alih oleh Otoritas Jasa Keuangan (OJK), memeriksa 178 kasus dugaan pelanggaran ditambah penyidikan pada 12 kasus dugaan tindak pidana di bidang pasar modal (Bapepam-LK, 2011). Kasus-kasus yang diselidiki antara lain dugaan pelanggaran atas ketentuan transaksi yang mengandung benturan kepentingan, transaksi material, keterbukaan pemegang saham tertentu, informasi atau fakta material yang harus segera diumumkan kepada publik, penyajian laporan keuangan, penggunaan dana hasil penawaran umum dan lainlain.

Tahun 2010, PT Waskita Karya (Persero) Tbk. diduga melakukan rekayasa laporan keuangan yakni ditemukan kelebihan pencatatan sebesar empat ratus milyar rupiah. Kasus-kasus kecurangan pelaporan keuangan lainnya yang terjadi 
di Bursa Efek Indonesia (BEI) dan telah dijatuhkan sanksi oleh Bapepam-LK diantaranya PT Bakrie and Brothers Tbk., PT Bakrie Sumatra Plantation Tbk., PT Energi Mega Persada Tbk., dan PT Benakat Petrolum Energy Tbk. karena terbukti memanipulasi laporan keuangannya melalui penyajian laba supaya tampak menguntungkan, dengan harapan publik tertarik membeli sahamnya untuk meningkatkan nilai saham (Ansar, 2012). Sepanjang tahun 2012 sampai 2014 dari 398 perusahaan yang terdaftar secara berturut-turut pada sektor nonkeuangan di BEI sebanyak 38 perusahaan atau 9,5\% dilaporkan melakukan pelanggaran peraturan Bapepam-LK.

Langkah untuk memutus rangkaian perilaku fraud didasarkan pada fraud triangle theory oleh Cressey (1953). Kekuatan fraud triangle theory adalah terdapat faktor endogen dan eksogen yang terkait dengan penyebab terjadinya kecurangan. Faktor endogen tersebut adalah tekanan atau motivasi (pressure) dan rasionalisasi (rationalization) pelaku, sedangkan faktor eksogennya adalah kesempatan (opportunity).

Tekanan (pressure) adalah dorongan yang menyebabkan seseorang melakukan kecurangan. Pada umumnya disebabkan oleh kebutuhan finansial dan tekanan situasional yang muncul karena adanya kewajiban keuangan yang melebihi batas kemampuan yang harus diselesaikan manajemen. SAS no. 99 menyatakan terdapat empat jenis tekanan yang mungkin mengakibatkan kecurangan pada laporan keuangan yaitu financial stability, external pressure, personal financial need, dan financial targets. 
Kesempatan (opportunity) adalah peluang yang memungkinkan kecurangan terjadi. Biasanya disebabkan karena pengendalian internal suatu organisasi yang lemah, kurangnya pengawasan, atau penyalahgunaan wewenang (Gagola, 2011). SAS no. 99 mengklasifikasikan peluang yang mungkin terjadi pada kecurangan laporan keuangan menjadi tiga kategori. Jenis peluang tersebut termasuk nature of industry, ineffective monitoring, dan organizational structure.

Rasionalisasi menjadi elemen penting dalam terjadinya kecurangan karena pelaku mencari pembenaran atas tindakannya. Pembenaran ini bisa terjadi saat pelaku merasa berhak mendapatkan sesuatu yang lebih (posisi, gaji, promosi) atau pelaku mengambil sebagian keuntungan karena perusahaan telah menghasilkan keuntungan yang besar. Penelitian menunjukkan bahwa kejadian kegagalan audit dan litigasi meningkat dengan cepat setelah adanya pergantian auditor (Stice, 1991; St Pierre dan Anderson, 1984; Loebbecke et al, 1989) maka pergantian auditor disertakan sebagai proksi untuk rasionalisasi (Skousen et al. 2009).

Skousen et al. (2009) mengembangkan variabel yang berfungsi sebagai ukuran proksi fraud triangle. Hasilnya, secara empiris faktor pressure yaitu financial stability, external pressure, dan personal financial need secara signifikan berhasil mendeteksi fraud. Dua faktor opportunity yaitu ineffectice monitoring dan organizational structure juga terbukti mampu mendeteksi perilaku fraud di perusahaan.

Gagola (2011) melakukan penelitian secara empiris yang mengkaji efektivitas teori Cressey (1953) dengan mengembangkan variabel yang berfungsi sebagai ukuran proksi untuk tekanan, kesempatan, dan rasionalisasi dan menguji 
variabel-variabel ini menggunakan informasi umum yang tersedia. Selanjutnya Hasnan et al. (2013) melakukan penelitian di Malaysia. Temuannya menunjukkan bukti bahwa di Negara berkembang, masih lemahnya kelembagaan, rendahnya kesadaran pentingnya lingkungan audit eksternal, dan aturan akuntansi yang memungkinkan fleksibilitas laporan keuangan berimplikasi terhadap praktik kecurangan dalam pelaporan keuangan.

Amara et al. (2013) meneliti keefektifan teori fraud triangle pada 80 perusahaan di Perancis. Hasil penelitiannya menunjukkan bahwa faktor pressure merupakan faktor utama yang menyebabkan terjadinya kecurangan pelaporan keuangan di Perancis. Di Indonesia, Putra dan Fitriany (2015) meneliti faktorfaktor yang bisa mencegah dan mendeteksi accounting irregularities dengan pendekatan fraud triangle. Perusahaan yang dikategorikan fraud didasarkan pada pelanggaran peraturan VIII.G.7 dan UUPM No. 69. Hasilnya menunjukkan bahwa faktor pressure yaitu financial stability dan financial target berpengaruh terhadap penyimpangan akuntansi. Nature of industry dan ineffectiveness of internal control juga terbukti mampu mendeteksi terjadinya fraud sesuai dengan faktor opportunity pada teori fraud triangle.

Sesuai dengan uraian di atas, penelitian ini dimaksudkan untuk mendeteksi fraudulent financial reporting berdasarkan fraud triangle theory yaitu pressure, opportunity, dan rationalization. Penelitian ini mengkaji kasus pelanggaran emiten di Indonesia atas Peraturan Nomor VIII.G.7 sesuai dengan Keputusan Ketua Bapepam-LK Nomor KEP-347/BL/2012 tentang penyajian dan pengungkapan laporan keuangan emiten atau perusahaan publik dan Peraturan 
I Gusti Putu Oka Surya Utama, I Wayan Ramantha dan I Dewa Nyoman Badera. Analisis Faktor..

Nomor IX.E.2 sesuai dengan Keputusan Ketua Bapepam-LK Nomor KEP614/BL/2011 tentang transakasi material dan perubahan kegiatan usaha utama. Penelitian ini didasarkan pada data internal OJK sebagai otoritas yang berwenang atas pengawasan pasar modal Indonesia dengan maksud lebih bisa memberikan keyakian atas data yang valid dan akurat untuk kategori perusahaan fraud di Indonesia.

Berdasarkan ulasan tersebut maka rumusan permasalahannya adalah apakah financial stability, external pressure, personal financial need, financial targets, nature of industry, ineffective monitoring, organizational structure, dan auditor switching berpengaruh pada fraudulent financial reporting?

Sesuai dengan rumusan masalah yang diuraikan di atas maka tujuan dari penelitian ini adalah untuk mendapatkan bukti empiris pengaruh financial stability, external pressure, personal financial need, financial targets, nature of industry, ineffective monitoring, organizational structure, dan auditor switching pada fraudulent financial reporting.

Hasil penelitian ini mampu berkontribusi dalam menjelaskan teori agensi dan fenomena-fenomena sesuai fraud triangle theory yang relevan dengan kondisi di Indonesia. Bagi manajemen puncak perusahaan, penelitian ini dapat memberikan informasi pendeteksian potensi tindakan kecurangan untuk merancang kebijakan pencegahan tindakan kecurangan. Bagi investor, penelitian ini bisa memberikan wawasan model prediksi perusahaan yang terindikasi fraud untuk menghindari kerugian dalam berinvestasi. Penelitian ini juga bisa digunakan untuk merancang regulasi yang mengatur komposisi manajemen, 
direksi, dan komisaris pada perusahaan dengan kepemilikan terafiliasi di Indonesia serta regulasi pencegahan pergantian auditor secara voluntary dengan motif tertentu.

Fraud triangle theory yang dicetuskan oleh Cressey (1953) mempunyai tiga kondisi yang umumnya hadir pada saat fraud terjadi yaitu tekanan atau pressure, peluang atau opportunity, dan rasionalisasi atau rationalization (Turner et al., 2003). Manajemen mendapat pressure untuk melakukan kecurangan karena pertumbuhan operasi yang tidak sebaik capaian kinerja pesaing atau rata-rata industry merupakan aspek pengukuran financial stability. Kerugian dan pelangaran perjanjian utang terkait dengan external pressure. Adanya kebutuhan eksekutif yang bertindak sebagai pemilik perusahaan dalam unsur personal financial need dipengaruhi oleh penurunan pasar dan nilai saham. Serta ditetapkannya target laba yang tidak realistis untuk mencapai prediksi analisis merupakan aspek pengukuran financial target.

Rendahnya mekanisme pengendalian internal dan pengawasan merupakan permasalahan utama penyebab opportunity itu muncul. Ketidakefektifan pengendalian internal meliputi lingkungan pengendalian internal dan aktivitas atau prosedur pengendalian merupakan faktor yang mengindikasikan ineffective monitoring perusahaan. Nature of industry perusahaan disebabkan oleh ketidakandalan sistem akuntansi dan kompleksitas peraturan akuntansi. Organizational structure ditunjukkan oleh kualitas kinerja, akses informasi untuk mendeteksi tindakan illegal, dan kompleksitas struktur organisasi. 
Sikap atau karakter adalah apa yang menyebabkan satu atau lebih individu untuk secara rasional melakukan fraud. Ketika integritas manajemen dipertanyakan, keandalan laporan keuangan diragukan. Jika manajemen memiliki kendali untuk menentukan auditor termasuk mengatur waktu perikatan kerjasama dengan auditor maka akan lebih mudah untuk membenarkan (rationalization) perilaku kecurangannya.

Financial stability merupakan keadaan yang menggambarkan kondisi ketidakstabilan keuangan perusahaan (Skousen et al. 2009). Loebbecke et al. (1989) serta Bell et al. (1991) menunjukkan bahwa kasus ketika perusahaan mengalami pertumbuhan industri di bawah rata-rata, manajemen mungkin untuk melakukan manipulasi laporan keuangan untuk meningkatkan prospek perusahaan. Berdasarkan ulasan tersebut, hipotesis yang diajukan yaitu: $\mathrm{H}_{1}$ : Financial Stability berpengaruh positif pada Fraudulent Financial Reporting.

Lou dan Wang (2009) menyatakan risiko salah saji material yang lebih besar akibat kecurangan dapat diidentifikasi pada perusahaan yang mengalami tekanan eksternal. Tekanan dari kreditur berpotensi meningkatkan tindakan manipulatif manajemen dengan tujuan menunjukkan kecukupan ketersediaan dana untuk melunasi utang perusahaan. Berdasarkan ulasan tersebut, hipotesis yang diajukan yaitu:

$\mathrm{H}_{2}$ : External Pressure berpengaruh positif pada Fraudulent Financial Reporting.

Beasley (1996), COSO (1999), dan Dunn (2004) menunjukkan bahwa ketika eksekutif perusahaan memiliki peranan keuangan yang kuat dalam perusahaan, personal financial need dari eksekutif perusahaan tersebut akan turut 
terpengaruh oleh kinerja keuangan perusahaan. Semakin tinggi persentase kepemilikan saham oleh orang dalam maka praktik fraud dalam memanipulasi laporan keuangan semakin bertambah. Berdasarkan ulasan tersebut, hipotesis yang diajukan yaitu:

$\mathrm{H}_{3}$ : Personal Financial Need berpengaruh positif pada Fraudulent Financial Reporting.

Summers dan Sweeney (1998) menyatakan bahwa Return on Asset (ROA) sering digunakan dalam menilai kinerja manajer. Semakin rendah capaian ROA tahun sebelumnya, memicu perusahaan untuk menentukan target keuangan yang lebih tinggi di tahun berikutnya untuk memperbaiki kinerja perusahaan maka manajemen semakin rentan melakukan kecurangan yang serius. Berdasarkan ulasan tersebut, hipotesis yang diajukan yaitu:

$\mathrm{H}_{4}$ : Financial Targets berpengaruh negatif pada Fraudulent Financial Reporting. Nature of Industry dalam teori fraud triangle menunjukkan sifat alami operasional sebuah industri yang memberikan kesempatan bagi seseorang untuk melakukan kecurangan dengan mengestimasi saldo akun cadangan penurunan nilai piutang secara subyektif. Berdasarkan ulasan tersebut, hipotesis yang diajukan yaitu:

$\mathrm{H}_{5}$ : Nature of Industry berpengaruh positif pada Fraudulent Financial Reporting.

Beasley et al. (2010) mengamati bahwa kejadian kecurangan di perusahaan akan menurun selama angota komite audit bekerja secara efektif. Jumlah komite audit yang besar berhubungan dengan rendahnya kejadian kecurangan. Berdasarkan ulasan tersebut, hipotesis yang diajukan yaitu:

$\mathrm{H}_{6}$ : Ineffective Monitoring berpengaruh negatif pada Fraudulent Financial Reporting. 
Haniffa dan Hudaib (2006) menyatakan bahwa jabatan direksi di luar perusahaan dapat menguntungkan sebagai sumber informasi berkaitan dengan kebijakan-kebijakan baru, rahasia dagang, dan praktik antara perusahaan yang dapat memberikan kinerja lebih baik. Discretionary power direksi akan dimanfaatkan untuk menegakkan kebijakan dalam rangka mencegah fraud. Berdasarkan ulasan tersebut, hipotesis yang diajukan yaitu:

$\mathrm{H}_{7}$ : Organizational Structure berpengaruh negatif pada Fraudulent Financial Reporting.

Lou dan Wang (2009) menyatakan bahwa sebuah perusahaan bisa mengganti auditor untuk mengurangi kemungkinan pendeteksian kecurangan laporan keuangan oleh pihak auditor. Strategi manajemen secara voluntary mengganti auditor memudahkannya untuk merasionalisasi perilaku kecurangann. Berdasarkan ulasan tersebut, hipotesis yang diajukan yaitu:

$\mathrm{H}_{8}$ : Auditor Switching berpengaruh positif pada Fraudulent Financial Reporting

\section{METODE PENELITIAN}

Penelitian ini dilaksanakan pada perusahaan-perusahaan nonkeuangan yang listed di Bursa Efek Indonesia periode 2012-2014. Tahun keuangan 2012-2014 digunakan sebagai tahun pengamatan dengan pertimbangan karena peraturan VIII.G.7 dan peraturan nomor IX.E.2 mulai berlaku untuk laporan keuangan yang berakhir pada 31 Desember 2012.

Sumber data adalah data sekunder eksternal yang diperoleh peneliti secara tidak langsung melalui perantara, seperti orang lain atau dokumen (Sugiyono, 2013: 193). Data yang diambil terdiri dari laporan auditor independen, informasi multijabatan direksi, dan data perusahaan-perusahaan yang melakukan fraud yang 
merupakan data kualitatif dan laporan keuangan perusahaan yang merupakan data kuantitatif. Data laporan keuangan auditan yang dianalisis dalam penelitian ini diperoleh dari website Bursa Efek Indonesia (www.idx.co.id) dan diperoleh melalui situs website resmi masing-masing perusahaan. Perusahaan yang bergerak pada sektor keuangan tidak digunakan dalam penelitian ini karena regulasi penyajian laporan keuangannya berbeda dengan perusahaan nonkeuangan sebagaimana diatur dalam Peraturan Bank Indonesia (PBI). Perbedaan tersebut meliputi penyajian informasi piutang usaha dan persediaan dalam laporan posisi keuangan perusahaan sektor keuangan.

Populasi dalam penelitian ini adalah seluruh perusahaan nonkeuangan yang terdaftar di Bursa Efek Indonesia periode 2012-2014. Sampel penelitian dipilih berdasarkan metode nonprobabilitas dengan kriteria tertentu. Sampel diambil secara berpasangan antara kategori fraud firm dengan nonfraud firm berdasarkan model Owens et al. (2009). Satu fraud firm dipasangkan dengan dua nonfraud firm, kecuali terdapat kurang dari dua nonfraud firm pada industri yang sama (Zmijewski, 1984).

Dependent variable yaitu fraudulent financial reporting didasarkan pada perusahaan yang melakukan pelanggaran terhadap peraturan Bapepam-LK nomor VIII.G.7 dan peraturan nomor IX.E.2. Fraud firm diberi kode 1 nonfraud firm diberi kode 0 .

Financial stability diukur menggunakan proksi tingkat pertumbuhan aset. yang merupakan outlook atas kekayaan perusahaan. Tingkat pertumbuhan aset diukur dengan formula sebagai berikut (Skousen, 2009). 
Pertumbuhan aset $=\frac{\text { Total ase }_{\mathrm{t}}-\text { Total }_{\text {aset }} \mathrm{t}-1}{\text { Total }_{\text {aset }} \mathrm{t}-1} \times 100 \%$

(1)

Leverage digunakan untuk mendefisikan tekanan dari pihak eksternal terhadap manajemen yang menunjukkan seberapa banyak aset perusahaan yang dibiayai dengan utang (Person, 1999). Formulasi perhitungan leverage adalah sebagai berikut (Lou dan Wang, 2009).

Leverage $=\frac{\text { Total Utang }}{\text { Total Aset }}$

Personal Financial Need diproksikan dengan kepemilikan saham pihak internal perusahaan, akibatnya yang bersangkutan merasa punya hak klaim atas kekayaan perusahaan dari pembagian dividen (Dunn, 2004). Kepemilikan pihak internal dihitung dengan cara sebagai berikut (Skousen, 2009).

Insider Ownership $=\frac{\text { Total Saham yang Dimiliki Pihak Internal }}{\text { Total Saham Biasa yang Beredar }} \times 100 \%$

Efisiensi penggunaan aset perusahaan untuk mencapai laba ditunjukkan oleh rasio return on total asset (ROA) tahun sebelumnya ( $\mathrm{t}-1)$ yang digunakan sebagai proksi financial target. ROA dihitung dengan formula sebagai berikut (Lou dan Wang, 2009).

Return on Total Asset $=\frac{\text { Laba Setelah Pajak }}{t-1}$

Keleluasaan subyektifitas manajemen menentukan nilai cadangan kerugian penurunan nilai piutang dalam komponen piutang bersih dianggap sebagai opportunity sebagai akibat dari aktivitas nature of industry. Formulasi untuk menghitung rasio perubahan piutang sebagai berikut (Skousen, 2009). 
Rasio Perubahan Piutang $=\frac{\text { Piutang }_{t}}{\text { Penjualan }_{t}}-\frac{\text { Piutang }_{t-1}}{\text { Penjualan }_{t-1}} \ldots \ldots \ldots \ldots \ldots \ldots$

Penelitian ini memproksikan ineffective monitoring melalui proporsi komite audit independen yang dimiliki perusahaan. Proporsi komite audit independen dihitung dengan cara sebagai berikut (Skousen, 2009).

Komite Audit Independen $=\frac{\text { Jumlah Komite Audit Independen }}{\text { Jumlah Komite Audit }}$

Organizational structure pada penelitian ini diproksikan dengan multijabatan dewan direksi yang diyakini berkontribusi terhadap pencegahan perilaku fraud organisasi karena direksi memiliki kesempatan untuk membandingkan kebijakan dan praktik manajemen. Proporsi multijabatan dewan direksi dihitung dengan cara sebagai berikut (Hasnan et al., 2013).

Multijabatan $=\frac{\text { Jumlah Direksi yang Menjabat di Perusahaan Lain }}{\text { Jumlah Direksi Perusahaan }} \ldots \ldots \ldots \ldots \ldots . . . . .$.

Perusahaan melakukan pergantian auditor untuk mengurangi kemungkinan terdeteksinya kecurangan dalam pelaporan keuangan. Auditor switching diukur menggunakan variabel dummy. Angka 1 diberikan jika perusahaan melakukan pergantian auditor secara voluntary. Angka 0 jika perusahaan tidak melakukan pergantian auditor secara voluntary. Tahun 2012 diasumsikan sebagai tahun pertama perikatan.

Analisis data yang digunakan adalah analisis regresi logistik karena variabel terikatnya adalah fraudulent financial reporting yang merupakan data 
I Gusti Putu Oka Surya Utama, I Wayan Ramantha dan I Dewa Nyoman Badera. Analisis Faktor..

kualitatif yang menggunakan variabel dummy dan variabel bebasnya merupakan kombinasi antara variabel metrik dan non-metrik (Sumodiningrat, 2007: 334).

\section{HASIL DAN PEMBAHASAN}

Jumlah pengamatan keseluruhan dalam penelitian disajikan pada Tabel 1.

Tabel 1.

Jumlah Pengamatan Penelitian

\begin{tabular}{|c|c|}
\hline No & Jumlah \\
\hline Fraud firm selama periode $2012-2014$ & 18 \\
\hline Nonfraud firm periode $2012-2014$ & 34 \\
\hline Jumlah Sampel Akhir & 52 \\
\hline Tahun Pengamatan & 3 \\
\hline Jumlah Pengamatan & 156 \\
\hline
\end{tabular}

Uji Beda Parametrik Independent Sample t-Test digunakan untuk untuk membandingkan antara kelompok fraud firm dan kelompok nonfraud firm mempunyai nilai rata-rata yang sama ataukah tidak sama secara signifikan berdasarkan total asetnya. Hasil uji beda parametrik independent sample t-Test dapat dilihat pada Tabel 2.

Tabel 2.

Hasil Uji Beda Parametrik Independent Sample t-Test

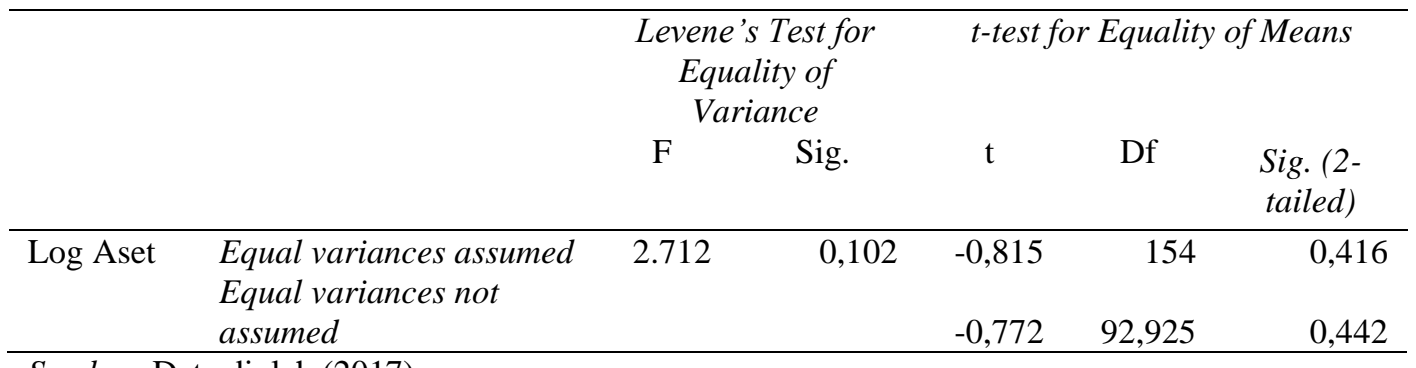

Sumber: Data diolah (2017)

Berdasarkan Tabel 2, dapat diketahui bahwa nilai Sig. (2-tailed) equal variances assumed sebesar 0,416 lebih besar dari sig $\alpha$ sebesar 0,05 . Ini berarti tidak terdapat perbedaan kelompok fraud firm dan nonfraud firm berdasarkan total 
asetnya, maka dapat disimpulkan perusahaan sampel dapat dibandingkan dan digunakan dalam penelitian ini.

Uji statistik deskriptif ditunjukkan pada Tabel 3 yang menggambarkan deskripsi sampel penelitian.

Tabel 3.

Hasil Statistik Deskriptif

\begin{tabular}{|c|c|c|c|c|c|c|c|c|}
\hline \multirow[b]{2}{*}{ Variabel } & \multicolumn{4}{|c|}{ Fraud Firm } & \multicolumn{4}{|c|}{ Nonfraud Firm } \\
\hline & Min & Mak & Mean & $\begin{array}{l}\text { Standar } \\
\text { Deviasi }\end{array}$ & Min & Mak & Mean & $\begin{array}{l}\text { Standar } \\
\text { Deviasi }\end{array}$ \\
\hline financial & & & & & & & & \\
\hline $\begin{array}{l}\text { stability } \\
\text { external }\end{array}$ & $-8,43$ & 25,72 & 1,64 & 4,19 & $-2,39$ & 3,53 & 0,31 & 0,91 \\
\hline $\begin{array}{l}\text { pressure } \\
\text { personal }\end{array}$ & 12,05 & 94,50 & 50,16 & 19,01 & 0,16 & 67,53 & 22,01 & 18,81 \\
\hline financial need & 0,00 & 74,19 & 11,02 & 20,40 & 0,00 & 56,88 & 3,00 & 9,47 \\
\hline financial target & $-75,60$ & 19,50 & $-2,91$ & 15,19 & $-61,59$ & 54,33 & 3,55 & 12,78 \\
\hline $\begin{array}{l}\text { nature of } \\
\text { industry } \\
\text { ineffective }\end{array}$ & $-0,61$ & 4,11 & 0,18 & 0,76 & $-13,57$ & 2,51 & $-0,17$ & 1,57 \\
\hline monitoring & 0,00 & 1,00 & 0,63 & 0,35 & 0,00 & 1,00 & 0,66 & 0,34 \\
\hline $\begin{array}{l}\text { organizational } \\
\text { structure } \\
\text { auditor }\end{array}$ & 0,00 & 1,00 & 0,24 & 0,27 & 0,00 & 1,00 & 0,43 & 0,27 \\
\hline switching & 0,00 & 1,00 & 0.50 & 0,50 & 0,00 & 1,00 & 0,23 & 0,42 \\
\hline
\end{tabular}

Financial stability pada kelompok sampel fraud firm memiliki rata-rata sebesar 1,64 dan pada perusahaan nonfraud memiliki nilai rata-rata sebesar 0,31. Pengungkapan perubahan aset yang lebih tinggi oleh kelompok fraud firm mengindikasikan perilaku manipulatif manajemen untuk menampilkan kekayaan perusahaan yang terus bertumbuh untuk menyembunyikan ketidakstabilan kondisi perusahaan.

External pressure dari fraud firm memiliki nilai rata-rata sebesar 50,16 dan pada perusahaan nonfraud memiliki nilai rata-rata sebesar 22,01. Komposisi utang yang lebih besar pada fraud firm meningkatkan tekanan yang dirasakan 
manajemen sehingga timbul perilaku moral hazard untuk memanipulasi pelaporan keuangan agar tampak meyakinkan bagi kreditur.

Personal financial need pada fraud firm memiliki nilai rata-rata sebesar 11,02 dan pada perusahaan nonfraud memiliki nilai rata-rata sebesar 3,00. Pada fraud firm, ketergantungan yang lebih besar oleh para pemilik internal terhadap klaim kekayaan perusahaan (dividen) menstimulasi keinginan manajemen untuk menyajikan laba yang tinggi dan memengaruhi kebijakan keuangan perusahaan untuk kepentingan sendiri.

Financial target pada kelompok sampel fraud firm memiliki nilai rata-rata yaitu sebesar -2,91 dan pada perusahaan nonfraud memiliki rata-rata sebesar 3,55. Tingkat ROA yang rendah pada fraud firm mendorong manajemen memanipulasi laba perusahaan demi memenuhi target keuangan akibat capaian profitabilitas yang buruk di tahun sebelumnya.

Nature of industry dari fraud firm memiliki nilai rata-rata sebesar 0,18 dan pada perusahaan nonfraud memiliki nilai rata-rata sebesar $-0,17$. Pengakuan terhadap nilai piutang bersih yang lebih tinggi oleh manajemen fraud firm menggambarkan manipulasi dilakukan dengan memanfaatkan aspek subyektifitas dalam menentukan cadangan kerugian penurunan nilai piutang dalam pelaporan keuangan.

Ineffective monitoring pada fraud firm memiliki nilai rata-rata sebesar 0,63 dan pada perusahaan nonfraud memiliki nilai nilai rata-rata sebesar 0,66. Persentase rata-rata komite audit pada fraud firm lebih kecil daripada nonfraud 
firm yang menunjukkan pengawasan pada nonfraud firm lebih optimal dibandingkan dengan fraud firm.

Organizational structure pada kelompok fraud firm memiliki nilai ratarata sebesar 0,24 dan pada perusahaan nonfraud memiliki nilai rata-rata sebesar 0,43. Hal ini menunjukkan bahwa direksi di fraud firm tidak akan memiliki informasi dan pengetahuan yang cukup untuk meminimalisir praktik fraud karena tidak banyak dipercaya untuk menduduki jabatan di perusahaan lain.

Auditor switching dari fraud firm memiliki nilai rata-rata sebesar 0,50 dan pada perusahaan nonfraud memiliki nilai rata-rata sebesar 0,23. Hal ini menunjukkan penggantian auditor secara voluntary lebih sering terjadi pada kelompok fraud firm dengan tujuan rasionalisasi untuk menutupi kecurangan manajemen.

Hosmer and Lemeshow's Goodness Of Fit Test digunakan untuk menilai layak tidaknya suatu model regresi. Hasil uji menunjukkan nilai signifikansi yaitu 0,945 (sig > 0,05). Berarti nilai observasi mampu diprediksi oleh model dengan kata lain model dianggap fit.

Overall model fit dinilai dengan melakukan perbandingan angka pada -2 Log Likelihood (-2LL) Block 0: Beginning dengan angka pada -2 Log Likelihood (-2LL) Block 1: Method. -2LL awal menunjukkan nilai 201,250. Kemudian mengalami penurunan menjadi 99,978 pada -2LL akhir ketika keenam variabel bebas pada model regresi telah dimasukkan. Nilai -2LL yang mengalami penurunan nilai membuktikan bahwa model regresi yang dirumuskan cocok dengan data. 
Hasil Nagelkerke $R$ Square menunjukkan besarnya nilai koefisien determinasi sebesar 0,659 yang artinya variabel independen mampu menjelaskan variabilitas variabel dependen sebesar 65,9 persen, maka sebanyak 34,1 persen dipengaruhi oleh variabel lain yang tidak dimasukkan dalam model.

Pengujian regresi logistik disajikan secara ringkas sebagai berikut ini.

Tabel 4.

Hasil Uji Regresi Logistik

\begin{tabular}{cccc}
\hline $\begin{array}{c}\text { Jenis } \\
\text { Pengujian }\end{array}$ & $\begin{array}{c}\text { Menilai } \\
\text { kelayakan } \\
\text { model regresi }\end{array}$ & Menilai keseluruhan model & $\begin{array}{c}\text { Koefisien } \\
\text { determinasi }\end{array}$ \\
\hline \multirow{2}{*}{ Hasil Uji } & Signifikansi & -2 Log Likelihood & $\begin{array}{c}\text { Nagelkerke } R \\
\text { Square } \\
\end{array}$ \\
0,945 & Block $0=201,250 \quad$ Block $1=99,978$ & 0,659 \\
\hline
\end{tabular}

Sumber: Data diolah (2017)

Tabel klasifikasi memrediksi kemungkinan perusahaan melakukan fraud adalah sebesar 75,9 persen, terdapat 41 perusahaan yang diprediksi akan melakukan fraud dari total 54 perusahaan yang fraud. Prediksi pada perusahaan nonfraud adalah 92,2 persen, terdapat 94 perusahaan yang diprediksi tidak akan melakukan kecurangan (nonfraud firm) dari total 102 perusahaan nonfraud.

Hasil pengujian membuktikan bahwa model terbebas dari gejala multikolinearitas karena seluruh koefisien korelasi diantara variabel menunjukan nilai lebih rendah dari 0,8 .

Model regresi logistik yang terbentuk disajikan dalam Tabel 4 dengan Variables in The Equation sebagai berikut ini.

$$
\begin{aligned}
& \ln \frac{\mathrm{FFR}}{1-\mathrm{FFR}}=-4,797+0,380 \mathrm{FS}+0,092 \mathrm{EP}+0,051 \mathrm{PFN}-0,032 \mathrm{FT}+0,245 \mathrm{NI}+ \\
& 0,669 \text { IM - 2,106 OS + 1,308 AS }
\end{aligned}
$$


Tabel 5.

Tabel Variable in Equation

\begin{tabular}{lccc}
\hline \multicolumn{1}{c}{ Variabel } & $\mathrm{B}$ & Standar Eror & Signifikansi \\
\hline Financial Stability (FS) & 0,380 & 0,175 & 0,030 \\
External Pressure (EP) & 0,092 & 0,018 & 0,000 \\
Personal Financial Need (PFN) & 0,051 & 0,018 & 0,005 \\
Financial Target (FT) & $-0,032$ & 0,018 & 0,086 \\
Nature of Industry (NI) & 0,245 & 0,622 & 0,693 \\
Ineffective Monitoring (IM) & 0,669 & 0,743 & 0,368 \\
Organizational Structure (OS) & $-2,106$ & 1,012 & 0,037 \\
Auditor Switching (AS) & 1,308 & 0,558 & 0,019 \\
Konstanta & $-4,797$ & 1,018 & 0,000 \\
\hline Sumber: Data dian
\end{tabular}

Sumber: Data diolah (2017)

Hipotesis pertama $\left(\mathrm{H}_{1}\right)$ menyatakan bahwa financial stability berpengaruh positif pada fraudulent financial reporting. Hasil pengujian menunjukkan tingkat signifikansi yaitu 0,030 lebih rendah dari tingkat kesalahan $(\alpha=5 \%)$. Berdasarkan hal tersebut dapat disimpulkan bahwa financial stability berpengaruh positif pada fraudulent financial reporting atau dengan kata lain $\mathrm{H}_{1}$ diterima. Hal ini berarti bahwa peningkatan stabilitas perusahaan melalui pertumbuhan asetnya turut meningkatkan indikasi kemungkinan terjadinya kecurangan untuk menutupi kondisi keuangan perusahaan yang sebenarnya. Hasil penelitian mendukung teori agensi bahwa ketika manajemen merasa kinerjanya gagal atau tidak mampu menjamin kestabilan usaha perusahaan, maka manajer akan termotivasi melakukan fraud karena adanya pressure untuk membuktikan bahwa manajemen telah bekerja demi memaksimalkan kepentingan principal. Hasil penelitian ini konsisten dengan temuan Skousen et al. (2009), Martantya dan Daljono (2013), Hanifa dan Herry (2015), serta Tiffani dan Marfuah (2015). 
Hipotesis kedua $\left(\mathrm{H}_{2}\right)$ menyatakan bahwa external pressure berpengaruh positif pada fraudulent financial reporting. Hasil pengujian menunjukkan tingkat signifikansi yaitu 0,000 lebih rendah dari tingkat kesalahan $(\alpha=5 \%)$. Berdasarkan hal tersebut dapat disimpulkan bahwa external pressure berpengaruh positif pada fraudulent financial reporting atau dengan kata lain $\mathrm{H}_{2}$ diterima. Ini berarti bahwa tekanan berlebihan dari pihak eksternal untuk memenuhi persyaratan dan kewajiban kredit akan meningkatkan motivasi manajemen melakukan kecurangan pada laporan keuangan. Motivasi penyajian informasi akuntansi yang manipulatif bertujuan untuk menampilkan performa keuangan untuk menjaga kepercayaan kreditur. Hasil penelitian ini konsisten dengan temuan Lou dan Wang (2009) dan Kurniawati dan Raharja (2012).

Hipotesis ketiga $\left(\mathrm{H}_{3}\right)$ menyatakan bahwa financial personal need berpengaruh positif pada fraudulent financial reporting. Hasil pengujian menunjukkan tingkat signifikansi yaitu 0,005 lebih rendah sama dengan dari tingkat kesalahan $(\alpha=5 \%)$. Berdasarkan hal tersebut dapat disimpulkan bahwa financial personal need berpengaruh positif pada fraudulent financial reporting atau dengan kata lain $\mathrm{H}_{3}$ diterima. Hal ini berarti bahwa semakin pemilik internal perusahaan menggantungkan kebutuhan keuangan pribadinya atas kekayaan perusahaan maka tingkat kemungkinan praktik kecurangan pelaporan keuangan akan semakin potensial. Kecurangan dilakukan manajemen dengan peran ganda sebagai pelaksana dan pemilik dengan membuat capaian performa perusahaan tertentu untuk memeroleh dividen dan return saham yang tinggi. Hasil penelitian ini konsisten dengan temuan Morck et al. (1988) dan Skousen et al. (2009) 
Hipotesis keempat $\left(\mathrm{H}_{4}\right)$ menyatakan bahwa financial targets berpengaruh negatif pada fraudulent financial reporting. Hasil pengujian menunjukkan tingkat signifikansi yaitu 0,086 lebih besar dari tingkat kesalahan $(\alpha=5 \%)$. Berdasarkan hal tersebut dapat disimpulkan bahwa financial targets tidak berpengaruh pada fraudulent financial reporting atau dengan kata lain $\mathrm{H}_{4}$ ditolak. Hal ini membuktikan bahwa tekanan pencapaian target keuangan tidak dijadikan dasar pertimbangan oleh manajemen untuk melakukan kecurangan pelaporan keuangan karena manajemen perusahaan cenderung konservatif melakukan kinerja keuangan. Selain itu posisi life cycle perusahaan juga memengaruhi ROA tidak selalu digunakan sebagai target keuangan. Misalnya ketika perusahaan dalam tahap introduction maka laba bukanlah target utama perusahaan melainkan market share (Schori dan Garee, 1998). Hasil penelitian ini konsisten dengan temuan Skousen et al. (2009) serta Rachmawati dan Marsono (2014).

Hipotesis kelima $\left(\mathrm{H}_{5}\right)$ menyatakan bahwa nature of industry berpengaruh positif pada fraudulent financial reporting. Hasil pengujian menunjukkan tingkat signifikansi yaitu 0,693 lebih besar dari tingkat kesalahan $(\alpha=5 \%)$. Berdasarkan hal tersebut dapat disimpulkan bahwa nature of industry tidak berpengaruh pada fraudulent financial reporting atau dengan kata lain $\mathrm{H}_{5}$ ditolak. Ini membuktikan bahwa penilaian subyektif atas akun tertentu adalah hal yang tak terhindarkan dari aktivitas alamiah dalam perusahaan sehingga tidak dianggap sebagai celah kesempatan untuk melakukan kecurangan pelaporan keuangan. Manajemen patuh pada peraturan VIII.G.7 Bapepam-LK poin c nomor 2, khususnya pengungkapan mengenai jumlah, alasan, dasar pembentukan, dan kecukupan cadangan 
penurunan nilai piutang tersebut. Hasil penelitian ini konsisten dengan temuan Skousen et al. (2009).

Hipotesis keenam $\left(\mathrm{H}_{6}\right)$ menyatakan bahwa ineffective monitoring berpengaruh negatif pada fraudulent financial reporting. Hasil pengujian menunjukkan tingkat signifikansi yaitu 0,368 lebih besar dari tingkat kesalahan $(\alpha$ $=5 \%$ ). Berdasarkan hal tersebut dapat disimpulkan bahwa ineffective monitoring tidak berpengaruh pada fraudulent financial reporting atau dengan kata lain $\mathrm{H}_{6}$ ditolak. Ini menunjukkan bahwa ketidakefektivan pengawasan oleh komite audit tidak berarti akan menyebabkan praktik kecurangan atas pelaporan keuangan semakin meningkat. Perusahaan telah menaati regulasi Keputusan Ketua Bapepam LK Nomor: Kep-643/BL/2012 tentang pembentukan dan pedoman pelaksanaan kerja komite audit untuk mencegah perusahaan melakukan fraud. Hasil penelitian ini konsisten dengan temuan Rahmanti dan Daljono (2013).

Hipotesis ketujuh $\left(\mathrm{H}_{7}\right)$ menyatakan bahwa organizational structure berpengaruh negatif pada fraudulent financial reporting. Hasil pengujian menunjukkan tingkat signifikansi yaitu 0,037 lebih rendah dari tingkat kesalahan $(\alpha=5 \%)$. Berdasarkan hal tersebut dapat disimpulkan bahwa organizational structure berpengaruh negatif pada fraudulent financial reporting atau dengan kata lain $\mathrm{H}_{7}$ diterima. Hal ini berarti bahwa struktur organisasi perusahaan dengan direksi yang memiliki kompleksitas jabatan di perusahaan lain akan meminimalisir terjadinya kecurangan pelaporan keuangan. Kepercayaan yang didapatkan direksi untuk memiliki jabatan di perusahaan lain membuat dirinya lebih kompeten dalam mengelola perusahaan terutama memberantas kecurangan 
sekaligus mengambil langkah kebijakan preventif munculnya praktik kecurangan di dalam perusahaannya. Hasil penelitian ini konsisten dengan temuan Albrecht $e t$ al. (2006) dan Hasnan et al. (2013).

Hipotesis kedelapan $\left(\mathrm{H}_{8}\right)$ menyatakan bahwa auditor switching berpengaruh positif pada fraudulent financial reporting. Hasil pengujian menunjukkan tingkat signifikansi yaitu 0,019 lebih rendah dari tingkat kesalahan $(\alpha=5 \%)$. Berdasarkan hal tersebut dapat disimpulkan bahwa auditor switching berpengaruh positif pada fraudulent financial reporting atau dengan kata lain $\mathrm{H}_{8}$ diterima. Hal ini berarti bahwa semakin tinggi intensitas pergantian auditor independen berakibat pada semakin mudahnya manajemen merasionalisasi tindakan kecurangannya dengan tujuan mengelabui auditor. Kuasa manajemen untuk mengganti auditor lama dan menunjuk auditor baru berakibat pada pembatasan akses informasi dan pemahaman auditor atas perilaku-perilaku manipulatif manajemen yang kemungkinan melakukan fraud. Hasil penelitian ini konsisten dengan temuan Loebbecke et al. (1989), Krishnan (1997), Shu (2000), serta Lou dan Wang (2009).

\section{SIMPULAN DAN SARAN}

Hasil penelitian mendukung fraud triangle theory bahwa potensi fraud di Indonesia dapat disebabkan oleh kombinasi faktor endogen (tekanan dan rasionalisasi) serta faktor eksogen (kesempatan). Faktor endogen dari tekanan (pressure) yaitu financial stability berpengaruh positif pada fraudulent financial reporting, external pressure berpengaruh positif pada fraudulent financial reporting, dan personal financial need berpengaruh positif pada fraudulent 
financial reporting. Dari unsur rasionalisasi (rationalization), auditor switching berpengaruh positif pada fraudulent financial reporting.

Di samping itu, pengaruh dari faktor eksogen berupa kesempatan (opportunity) yang memungkinkan fraud terjadi dibuktikan oleh organizational structure yang berpengaruh negatif pada fraudulent financial reporting. Sedangkan financial targets dari unsur pressure serta nature of industry dan ineffective monitoring dari unsur opportunity tidak berpengaruh pada fraudulent financial reporting.

Terdapat beberapa keterbatasan serta saran sehingga masih diperlukan pengembangan dan perbaikan pada penelitian-penelitian selanjutnya. Keterbatasan pada penelitian ini adalah jenis sanksi spesifik yang diberikan oleh OJK kepada perusahaan atas pelanggaran peraturan VIII.G.7 dan IX.E.2 belum diketahui. Bagi peneliti selanjutnya dapat mengklasifikasikan tingkat materialitas kecurangan perusahaan berdasarkan tingkat kecurangan rendah, moderat, tinggi, dan tidak melakukan kecurangan (nonfraud) sesuai sanksinya.

Ukuran financial targets pada penelitian ini hanya menggunakan rasio profitabilitas ROA sehingga tidak mampu menentukan secara khusus target keuangan perusahaan sesuai dengan siklus hidup bisnisnya. Penelitian selanjutnya disarankan untuk menentukan ukuran target keuangan yang relevan dengan tahapan siklus hidup perusahaan yang terdiri dari tahap introduction, growth, mature, dan decline.

Selain itu, penelitian ini membatasi klasifikasi perusahaan yang curang hanya didasarkan pada data internal OJK saja. Sehingga penelitian tidak bisa 
benar-benar menjamin sehat tidaknya perusahaan yang bebas dari fraudulent financial reporting. Investor dan kreditor dapat meningkatkan kewaspadaan terhadap interpretasi dan analisa penyajian pelaporan keuangan emiten agar terhindar dari informasi yang menyesatkan akibat praktik fraud. Model prediksi faktor-faktor fraud, ditambah dengan publikasi, berita, dan siaran pers yang dianggap valid memuat laporan perusahaan yang melakukan fraudulent financial reporting dapat dipertimbangkan untuk menghindari kerugian dalam berinvestasi atau memberikan pinjaman.

\section{REFERENSI}

Albrecht, W. S., Albrecht C. C., dan Albrecht C. D.. 2006. Fraud Examination. Second Edition. Thomson South-Western.

Amara, I., Anis B. A., dan Anis J. 2013. Detection of Fraud in Financial Statements : French Companies as a Case Study. International Journal of Academic Research in Business and Social Sciences, 3(5),pp : 456-472

American Institute of Certified Public Accountants (AICPA). 2002. Consideration Of Fraud In A Financial Statement Audit: Statement on Auditing Standards No.99. New York : AICPA.

Ansar, M. 2012. Analisis Faktor-Faktor yang Mempengaruhi Kecurangan Pelaporan Keuangan Pada Perusahaan Publik di Indonesia. Journal of Accounting, 4 (5), pp: 1-25.

Badan Pengawas Pasar Modal dan Lembaga Keuangan. 2011. Laporan Tahunan Badan Pengawas Pasar Modal dan Lembaga Keuangan. Jakarta.

Beasley, M. 1996. An Empirical Analysis Of The Relation Between The Board Of Director Composition And Financial Statement Fraud. The Accounting Review, 71(4), pp: 443-465.

Beasly, M., Dana J. V., dan Terry L.. 2010. Fraudulant financial reporting. [cited 2016 Mei 13]. Available from: URL: http://www.coso.org/documents/COSO FRAUDSTUDY2010_001.pdf 
Committee of Sponsoring Organizations of Treadway Commission (COSO). 1999. Fraudulent Financial Reporting: 1987-1997 - Analysis of US. New York: Public Companies.

Cressey, D. 1953. Other People's Money; A Study In The Social Psychology Of Embezzlement. Glencoe, IL: Free Press.

Dunn, P. 2004. The impact of insider power on fraudulent financial reporting. Jurnal of Management, 30 (3), pp: 397-412.

Gagola, A. S. C. 2011. Analisis Faktor Risiko Yang Mempengaruhi Kecenderungan Kecurangan Pelaporan Keuangan Perusahaan Publik Di Indonesia. (tesis). Semarang: Universitas Diponegoro.

Haniffa, R., dan Herry M. 2006. Corporate Governance Structure and Performance of Malaysian Listed Companies. Journal of Business Finance \& Accounting, 33 (7) \& (8), pp: 1034-1062.

Hasnan, Suhaily, Rashidah A. R., Sakthi M. 2013. Management Motive, Weak Governance, Earnings Management, and Fraudulent Financial Reporting: Malaysian Evidence. Journal of International Accounting Research, 12(1), pp: 127.

Institut Akuntan Publik Indonesia. 2011. Standar Profesional Akuntan Publik. Jakarta: Salemba Empat. Jakarta: Salemba Empat.

Krishnan, J., dan Jayanthi K. 1997. Litigation Risk And Auditor Resignations. Accounting Review, pp: 539-560.

Kurniawati, E. dan Surya R. 2012. Analisis Faktor-Faktor Yang Mempengaruhi Fraudulent financial reporting Dalam Perspektif Fraud Triangle. Diponegoro Journal of Accounting, pp: 1-30.

Loebbecke, J., Eining M., dan Willingham J. 1989. Auditor's experience with material irregularities: frequency, nature, and detestability. Auditing: A Journal of Practice and Theory 9 (1).

Lou, Y.I., dan Wang, M.L. 2009. Fraud Risk Factor of the Fraud Triangle Assesing the Likelihood of Fraudulent Financial Reporting. Journal of Business and Economic Research, 7(2), pp: 62-66.

Morck, Randall, Andrei S., dan Robert W. V. 1988. Management Ownership and Market Valuation An Empirical Analysis. Journal of Financial Economics, 20, pp: 293-315. 
Owens, J. L. A., Robinson D., dan Shelton S.W. 2009. The Association Between Audit Committee Characteristics, The Contracting Process and Fraudulent Financial Report. American Journal of Business, 24(1), pp: 57-68.

Putra, A. P. dan Fitriany. 2015. Fraud Triangle (Pressure, Opportunity, and Rationalization) and the Level of Accounting Irregularities in Indonesia. Simposium Nasional Akuntansi XVIII. Medan, 16-19 September 2015.

Rachmawati, K. K. dan Marsono. 2014. Pengaruh Faktor-Faktor Dalam Perspektif Fraud Triangle Terhadap Fraudulent Financial Reporting (Studi Kasus Pada Perusahaan Berdasarkan Sanksi Dari Bapepam Periode 2008-2012). Diponegoro Journal of Accounting, 3(2), pp: 1-14.

Rahmanti, Martantya M. dan Daljono. 2013. Pendeteksian Kecurangan Laporan Keuangan Melalui Faktor Risiko Tekanan Dan Peluang (Studi Kasus Pada Perusahaan Yang Mendapat Sanksi Dari Bapepam Periode 2002-2006). Diponegoro Journal of Accounting, 2(2), pp: 1-12.

Schori, T. R. dan Michael L. G. 1998. Like Products, Companies have Life Cycle. Marketing Views, 32 (13), pp: 4-20.

Shu, S. Z. 2000. Auditor resignations: clientele effects and legal liability. Journal of Accounting and Economics, 29(2), pp: 173 - 205.

Skousen, C.J., Smith, K.R, dan Wright, C.J. 2009. Detecting and Predicting Financial Statement Fraud: the Effectiveness of the Fraud Triangle and SAS No.99. Corporate and Firm Performance Advances in Financial Economics, 13, pp: 53-81.

St. Pierre, K. dan James A. A. 1984. An Analysis Of The Factors Associated With Lawsuits Against Public Accountants. Accounting Review, pp: 242-263.

Stice, J.D. 1991. Using Financial And Market Inform Ation To Identify PreEngagements Factors Associated With Lawsuits Against Auditors. The Accounting Review, pp: 516-533.

Sugiyono. 2013. Metode Penelitian Bisnis (Pendekatan Kuantitatif, Kualitatif dan $R \& D)$. Bandung: Alfabeta.

Summers, S., dan Sweeney J. 1998. Fraudulently misstated financial statements and insider trading: An Empirical analysis. The Accounting Review 73 (1), pp: 131-146.

Sumodiningrat, Gunawan. 2007. Ekonometrika Pengantar. Edisi Kedua. Yogyakarta: BPFE. 
Tiffani, L. dan Marfuah. 2015. Deteksi Fraudulent financial reporting Dengan Analisis Fraud Triangle Pada Perusahaan Manufaktur Yang Terdaftar Di Bursa Efek Indonesia. JAAI, 19(2), pp: 112-125.

Turner, J.L., Mock, T.J., dan Sripastava, R.P. 2003. An Analysis of the Fraud Triangle. Working Paper.

Zmijewski, M. E. 1984. Methodological Issues Related to The Estimation of Financial Distress Prediction Model. Journal of Accounting Research, 22, pp: 59 80 . 